\title{
Psychiatry in free fall: In pursuit of a semiotic foothold
}

\author{
Stepan Davtian, Tatyana Chernigovskaya \\ Dept. of Medicine, and Dept. of General Linguistics, \\ St. Petersburg State University \\ University emb. 11, 199034 St. Petersburg, Russia \\ e-mail: sdav@sd10294.spb.edu; tatiana@tc3839.spb.edu
}

\begin{abstract}
Diagnostics of a mental disorder completely bases on an estimation of patient's behaviour, verbal behaviour being the most important. The behaviour, in turn, is ruled by a situation expressed as a system of signs. Perception of a situation could be seen as a function, which depends on the context resulting from the previous situations, structuring personal world. So the world is not given - it is being formed while the person is in action. We argue that distinctive features of behaviour, including its abnormal variants, can be explained not in categories of characters and diseases but in terms of situations taking place in individual worlds. The situation in which a person perceives himself is not simply a site in a three-dimensional space at a certain moment, but a part of the world and an episode of his life. Like a text composed of words, individual world is composed of situations. Each of them needs certain context to cope with ambiguity. This context is induced by the world as a whole. And the world, in turn, is presented as a chain of situations. If the context cannot help to interpret a situation adequately, uncertainty can be eliminated by actions clarifying a situation, which is changed in a predictable way. Thus, purposeful activity, skills to make predictions and corrections of one's own actions are crucial. Weakness of any of them inevitably leads to the distortion of the presentation of the world, to wrong evaluation of situations and, as a result, to inadequate actions that finally reduce the activity as being ineffective. Thus, the lack of activity becomes the key factor in the development of disorder, being simultaneously its cause and effect. In periods of insufficient activity conditions for violated (and violating) sign processing arise. Possible variants of sign malfunction are: oligosemia (reduction of the number of perceivable signs), hyposemia (decrease of significance of signs), hypersemia (increase of significance of some signs at the expense of others), ambisemia (uncertainty of sign, when situation remains unclear), cryptosemia (recognition of signs not obvious for other observers), and parasemia (perverted interpretation of signs influenced by a false context).
\end{abstract}


Umwelt, as elaborated by Jakob von Uexküll, is a model (as developed by Thomas Sebeok), a model of the world, or, better, the worlds, as there are innumerable models constructed by different inhabitants of our planet. Everyone has its own Umwelt adapted to its specific needs (Uexküll 1928).

Non-human signs are everywhere, investigated by different branches of semiotics endeavouring to understand stars and rocks, plants and animals (Hoffmeyer 1996; Kull 1998; 2001). However, humans are the only living beings who know that there are signs, i.e. who have the ability to engage in acts of reflection and self-reflection thereby creating a semiosphere of a specific character (Lotman 1984; 1990). As Deely puts it when discussing Peirce's views, all thought is in signs (Deely 1982). Ethosemiotics, or teleosemiotics, was proposed by Ponzio and Petrilli when elaborating upon an earlier idea of the semiotic self (Sebeok 1979; Sebeok et al. 2001); and autosemiosis was defined as a universal principle of Nature to reflect itself (Seppänen 2003) making biosemiotic space still richer.

Is there any relation between semiotics and psychiatry? Is semiotics essential for an understanding of the causes of mental disorders? Psychosemiotics, acknowledged by many authors as a branch of the biosemiotic sciences, is a domain that fills a huge but very important gap in our knowledge of human nature and its deviations. According to Jakob von Uexküll (1973), "in terms of semioses, we can conceive our world as a permanent dialogue between self and non-self. The world appears, then, as answers from non-self to questions of self and answers of self to questions of non-self" (Th. v. Uexküll 1992: 459). The idea of 'symptom' as a sign that in pre-Newtonian days made medicine a semiotic discipline seems to be in need of further elaboration now, when a crisis of biomechanical paradigms has become evident. It has also become evident that Peirce's (1931-1958), Bakhtin's and Lotman's concepts of dialogue as a basis for any informational process are of the utmost importance when we attempt to understand semiosis as arising from the need for an interpreter (metainterpretation in Thure von Uexküll's terms). As Tarasti discusses in the existential semiotics (Tarasti 2000), the central point is to see signs from the inside. He also discriminates between strong and weak (inner) signs like those of a dream, or those created by an abnormal psyche. It should be stressed that weak signs can dynamically form a person's behaviour and be existentially vital to it. In order to distinguish weak from strong, a person must be involved in 
a Bakhtinian dialogical situation - while making efforts to understand the Other and his/her Umwelt (Bakhtin 1986).

When dealing with human behaviour and especially its deviations in pathology, the interpretation of signs becomes extremely important. A psychosemiotic approach can even change paradigms in practical medicine. The diagnostics of mental disorders, in contrast to those of somatic medicine, are completely based on an estimation of a patient's behaviour, verbal behaviour being of greatest importance. In this context Bateson's mind-processes and ecology of mind (Bateson 1972: 448-464) and Th. v. Uexküll's (1986) semiotic approach to medicine are of special interest.

Ignoring this approach is the main cause of the crisis in modern psychiatry, in which a nosological approach based on the triad 'symptom-syndrom-disease' still remains dominant. The nosological approach does not provide mechanisms for understanding what really happens with a patient, serving only as a tool for recognizing and describing a disease. It is no wonder, therefore, that certain supposedly internal factors hidden within the depths of the soul or brain of a patient appear to be the cause of insanity.

This situation arose from the Cartesian-Newtonian paradigm of the Universe and has the following implications for psychiatry: human beings explore the world existing apart from themselves. If a person acts inappropriately or makes irrelevant statements he is considered insane. Hence, in order to explain such behaviour, we necessarily have to study mentality and its 'organ' - the brain. It seems that the only way for scientific reasoning to proceed within the designated system of coordinates is again to search for a kind of an inner phlogiston inside combustible matter as the cause of disorder, as had been done centuries ago.

For our further reasoning it is important to admit that there are no such mysterious inner causes, but only certain variants of behaviour that seem to be abnormal. Then, the question should sound like: "Why does someone behave in one way and not in another?" And vice versa, question like "What is the cause for schizophrenia?" is a wrong question, as it has no reasonable answer. Usually we say: "He lies because he is a liar", "He wins because he is the strongest", "She helps because she is responsive". Curiously enough, most people are usually satisfied with such 'explanations'. However, if someone had not won he would not have been called 'the strongest'. If someone had not been lying he would not have been called 'a liar'. And finally, if I did 
not smoke I would not be a smoker. I am a smoker because I smoke. Being a smoker is not the reason for my smoking. And even at those times when I am not smoking I remain a smoker — especially for those who know that nasty habit of mine. Thus, we should avoid such 'explanations without explanations' and stop asking, "What is the reason that someone is a liar" instead of: "Why does he sometimes lie"?

Why do people behave differently in similar situations? What are the appropriate criteria for discriminating the normal, or reasonable, from the abnormal? Is it really possible to talk about 'similar situations' at all? What is the motivating mechanism of human behaviour in general and of an insane person in particular? And what is the role of language and of the world-view of a suffering person - primarily keeping in mind his semiotic nature? Unfortunately, we are able to think of the world existing outside of and apart from a person, but it is most difficult to think of a person existing outside the world and apart from it. Having acquired such an ability, we shall realize the impossibility of the world existing apart from us. And then we shall admit that neither individuals nor the world can exist separately from each other. An individual is not a part of the world; neither is the world a part of him. They act as figure and background for one another. Which is figure and which is background depends on one's point of view. The psychological barrier to such reasoning is as follows: if there is more than one person in the world, there is also more than one world in the Universe, which in this case would more appropriately be called the Multiverse.

Whoever or whatever an individual is, above all, he is a complex self-organizing and self-adjusting system. Any system like this engenders a certain amount of entropy that correlates with the degree of its complexity. Besides, all living systems aspire to maintain the most energy-efficient nonequilibrium and stationary condition known in biology as 'homeostasis'. For this purpose a system has to be active in order to eliminate entropy and acquire so-called negative entropy (or negentropy), which is an ordered structure of any nature: food, air, information etc. Thus, activity is a major need of living systems and provides for their integrity and capacity to function. The destruction of a system occurs when the maximum permissible level of entropy is attained, a condition that is equivalent to approaching the polar stationary state with a minimum of energy - equilibrium. The death 
of a system causes and signifies its total passivity, whereas the passivity of a system causes its death.

This brief synergetic digression is cited in order to reveal the widespread mistake of traditional rationality in the analysis of causeand-effect relationships in a 'stimulus-reaction' paradigm. Not reaction as a whole is the consequence of a stimulus, but only a type of reaction among a set of possible variants. An action itself is not necessarily the consequence of the causal influence of a stimulus. The need to act in general is primary in comparison to the need to act in some specific way. An organism can respond to a stimulus with total inactivity and, vice versa, an organism's activity without any obvious stimulus is also possible. A person is not a machine programmed for reactions that occur in response to a stimulus.

People live not in space and time where stimuli occur and where they have to react somehow, but in one or another situation where their well-being depends on a successful choice of action. Any human life can be represented as a sequence of personal situations. In the same situations different individuals would operate identically. However, in practice, situations are never the same and are never repeated. A threat on the life of one person can be a challenge or even light entertainment for another. Of importance is that similar perceptions of a situation dictate similar behaviour. In other words, individuals, both normal, and pathological, behave similarly in similar situations. So, the question "Why do people act differently in similar situations?" is irrelevant, as well as the answer: "Because they have different personalities".

In contrast to animals, humans live not simply in reality, but in a specifically structured reality, which refers to concept of 'a world'. Each person is the inhabitant of his own world. These worlds are mutually penetrable and form a metasystem, which we designate as 'Multiple Worlds'. Penetrability means that each person is capable of perceiving only his own world (part of which he evaluates as himself), whereas all other worlds are presented to him in their convolute and underside forms, looking like other people, i.e. person perceives other worlds only through their external forms - as other people. We have discussed the similarities and differences between individuals, but in the same way we can discuss the similarities and differences between such worlds. Hence, the different features of form of behaviour, including its abnormal variants, can be explained not as categories of characters and diseases but in terms of the situations taking place 
within individual worlds. Thus, people act differently because they live in different worlds.

It is time to ask: "Why are situations so ambiguous and what is the way to deal with the ambiguity"? We shall take advantage of an analogy: each word of a proposition has a complex set of meanings. Words receive certain value because of the fact that a proposition has a certain sense. If the sense is unclear, the context is not well determined; variations and mistakes in the interpretation of separate words become very probable. In turn, freedom of interpretation can result in a distortion of meaning. It will change the context, a change that will be reflected in the further interpretation of words.

The situation in which a person perceives himself is not simply a site in three-dimensional space at a certain moment, but a part of the world and an episode in his life. Just as a text consists of words, an individual's world is composed of situations. And each of situation needs a certain context in order to cope with ambiguity. Context is provided by the world as a whole. And the world, in turn, is presented as a chain of situations. More to the point, we should add that a person aspires to control a situation while the situation itself controls his behaviour.

Let us look at the behaviour of a person standing at a crossroads: the green light comes on and he crosses the road. The green traffic light is not the reason that he has crossed the road but only a regulator of his behaviour. The reason for this is that he has to go somewhere. The colour of the light is conventional but not accidental: green is associated with factors favourable to life while red - is associated with threatening factors. However, in order for the sign to be able to adjust someone's behaviour it is insufficient for it to have a meaning. It should also be significant: ignoring it will produce adverse consequences while paying attention to it, on the contrary, should lead to favourable consequences. Moreover, the sign serves as a sign to the degree to which it serves as a sign for others: there is no reason to wait for a green signal if drivers don't pay attention to it. As a rule, behaviour should not be controlled by factors which do not also control the behaviour of others.

It is impossible to remember the meanings and significance that billions of signs have for billions of people. Fortunately, we do not have to. The complete, integrated form of semiotic knowledge necessary for adaptive behaviour is just our belief that there is a world arranged in a determined, although not always clear, fashion. 
While keeping in mind the level of active signs, let us turn now to the mentally ill person, and consider examples of the two most prevalent pathological conditions: depressive and paranoidal.

\section{A. The depressive patient and his reality}

In fact, he is not just a person suffering from a bad mood. He feels insignificant, a person who does not control the situation and he feels as if nothing in the world depends on his actions. His activity is dramatically reduced: he does not see any sense in activity and does not feel any satisfaction either from the results of action or from the process of action. The feeling of a wholeness to life and even of a wholeness to his own presence in the world is lost. He seems to be not quite alive. It is not surprising, therefore, that thoughts of death dominate. Nothing is positive for him: in the care of relatives he sees only that he has become a burden for them; in the encouraging words of other people he notices hidden irony; if people leave him alone, he considers it a sign of oblivion. Even in another person's smiles he sees a sign of hopelessness. He does not remember his former successes, conceiving himself as a loser, and his entire life is perceived as a circuit of continuous mistakes. Having such an experience, the patient becomes more disinclined toward an active life as his passivity and feelings of despair and hopelessness accumulate. The idea of death becomes a positive value. From this moment on, the risk of suicide sharply grows.

Thus, the initial manifestation of depression (the periods of decreased activity arising cyclically) gradually changes the context of the patient's existence and, as a result, in subsequent situations negative values become more topical, confirming the dominant idea that everything is not only negative but even worse than it seemed before. The situation becomes still worse as the significance of life is diminished, the importance of all essentially decreases and, hence, the number of perceiving signs carrying a positive sense reduce. And finally, signs with negative content prominently arise from the general background, gradually filling all the semiotic space of the patient. The world becomes unipolar, nothing in it promises anything good; there is almost nothing to do in it; and it is not a place to live in. It all moves in a vicious circle: depression develops, the sufferings of the patient reach a culminating point, death, which had earlier symbolized 
absolute evil, becomes a blessing — the most desired event. The only reason for not committing suicide in this case is total apoplexy of the will.

\section{B. The paranoid patient and his reality}

Initially a paranoic is a person living in a world that is unsafe. The world is an arena for him, and his life is a struggle. He is a person who understands meanings, rather than feels senses: he is attuned to the analytical interpretation of signs rather than to the direct sensual perception of a situation as a whole. Thus, if he is intelligent enough, he might never fall ill. The level of intelligence defined semiotically is the amount of perceivable signs and the awareness of their meanings: intelligence is equivalent to the ability to operate optimally, taking all circumstances into account. Recent researches show that the intelligence of paranoid patients is roughly $10 \%$ lower than the average level in a population. Besides, the semiotic space for such individuals is wider, and the borders of their semantic fields are vague and fuzzy.

They appear in adverse situations more often than others; threatening feelings arise every time they face an indefinite situation - with signs that are not distinctly denotative. Although the ambiguity of a situation is overcome by context, there are cases when a context cannot help to interpret a situation adequately. In such cases uncertainty can be eliminated by taking action to clear up a situation which is changed in a predictable way. Otherwise, an alternative hypothesis is put forward, which also must be confirmed by practical experience. This is a way to overcome ambiguity and to form new necessary contexts.

Thus, purposeful activity, skills to make predictions, and corrections of one's own actions are crucial. Weakness in any of these areas inevitably leads to the distortion of representations of the world, to the wrong appreciation of a situation and, as a result, to inadequate actions. Without its clarifying contextual clues, the world becomes more and more unreliable, and situations become more unpredictable. Eventually, a feeling of confusion and fear of impending threats reaches a point when further life becomes impossible: the world can be hostile, bad, or any variant thereof, but it should be conceivable. However, a means for clarifying actions has already been foreclosed, because a person's activity only increases the adversity in a situation. 
Together with a reduction in activity, a simplification of behaviour and a loss of control of the situation, the representation of a hostile world occupied by persecutors supervising the life of a patient crystallizes. This is the price which is paid for the world to regain its distinctiveness. However, a new context gives knowledge of the hostile intentions of other people, which is fed by a feeling of being threatened and under the control of others. Any word, any act in the person's surroundings is now a sign of potential danger. Minimal activity, withdrawal from the world and other people, and keeping a safe distance from them is the most expedient strategy now. Interaction with the world decreases, and consequently representations of it lose validity. Alienation and apathy gradually grow: the world becomes impoverished, losing its colour, signs and significance. The patient's activity lessens - from this time on total passivity guaranties safety in the world where there is no longer anything to do.

In summary, we should mention again that the most significant primary manifestation in psychiatry is abnormal behaviour. This behaviour, in turn, is completely ruled by a situation expressed as a system of signs. A person's perception of a situation can be seen as a function that depends upon the context that results from previous situations that structure a person's world.

The world is not given; it is formed while a person is acting. Adequate personal world formation is possible only through successful behaviour based on the ability to predict and to make corrections if necessary. Thus, activity deficit becomes the motivating mechanism, the key factor in the development of a disorder, being simultaneously its cause and effect. In this respect, a final semiotic equivalent of disease, as it has been shown above, proves to be the simplification of person's world and behaviour, which is represented as a reduction in the number of perceivable signs (or oligosemia) and a decrease in the significance of signs in his life situations, their fragments and in the world as a whole (or hyposemia).

We consider that, along with a lack of activity, the second leading factor determining abnormal behaviour is the malfunction of signs (compare with Rudnev's understanding of psychopathology as hyperand hyposemiotization of reality - Rudnev 2002). This malfunction is related to such a fundamental feature of the sign as its ambiguity, which a healthy subject copes with during his activity. In periods of insufficient activity, conditions for violated sign processing arise. Several variants of such a violation are possible in addition to the 
oligo- and hyposemia mentioned above. Some of them we have tried to demonstrate in our clinical examples. We suggest the new terms for that:

- ambisemia - for the uncertainty of a sign when the situation remains unclear;

- cryptosemia - for the recognition of signs not obvious to other observers;

- parasemia - for the perverted interpretation of signs influenced by a false context; and

- hypersemia - for the increase in significance of some signs at the expense of others.

All of these conditions may be present in various proportions in any variation of abnormal behaviour. The particular structure of sign malfunction depends on such conditions as the initial features of the 'person-world' system, the origin of activity deficit and the duration of the disorder.

\section{Conclusion}

We must reject thinking of psychoses as disorders of the psyche. However difficult it is, the less we use the terms psyche, consciousness, or mind the better. Although there really are individuals who are called mentally ill, mental diseases themselves are no more than the offspring of our theoretical speculations. We perceive and evaluate what we from our inside think to be the outer world, while its specificity is caused by language and more broadly by individual semiotic maps. This means that we are never looking out upon the world, but rather drawing and extracting 'the external' world semiotically. That is why the approach to mental deviations should be much more complex, taking into account the egocentric nature of an individual semiosphere with its own co-ordinates through all axes. This inevitably leads us to a necessity — and a possibility — to develop an alternative approach to the psychiatric domain in accordance with the synthetic thinking currently under discussion in philosophy of science.

Following Vijver's (1999) paper on psychic closure, we argue that human beings are hierarchically organized and embedded in language and socio-cultural space - which is also hierarchical and subject to its own constraints in addition to biological development or pathological 
conditions; and further - it is most important to understand what makes up systems and how this understanding helps to realize sign functions within them. To understand the Other, who in the case discussed is a person exhibiting abnormal behaviour, we should reconstruct as thoroughly as possible his semiosphere, the Umwelt, and see how it functions for him, what signal-values are there (Hoffmeyer 1996), to understand what his signs mean to him. There is no way to recognize the semiosphere except in dialogue and by delicate language analysis, as we are language-determined systems, and this is species-specific. ${ }^{1}$

\section{References}

Bakhtin, Mikhail 1986. Speech Genres and Other Late Essays. (Eng. trans. by Vern W. McGee; ed. by Caryl Emerson and Michael Holquist.) Austin: University of Texas Press.

Bateson, Gregory 1972. Steps to an Ecology of Mind. New York: Ballantine Books.

Deely, John 1982. Introducing Semiotic: Its History and Doctrine. Bloomington: Indiana University Press.

Hoffmeyer, Jesper 1996. Signs of Meaning in the Universe. Bloomington: Indiana University Press.

Kull, Kalevi 1998. On semiosis, Umwelt, and semiosphere. Semiotica 120(3/4): 299-310.

— 2001. Jakob von Uexküll: An introduction. Semiotica 134(1/4): 1-59.

Lotman, Juri 1984. O semiosfere. Sign Systems Studies [Trudy po znakovym sistemam] 17: 5-23.

- 1990. Universe of the Mind: A Semiotic Theory of Culture. London: I. B. Tauris.

Peirce, Charles S. 1931-1958. Collected papers of Charles Sanders Peirce. Ed. by Charles Hartshorne, Paul Weiss, Arthur W. Burks. Cambridge: Belknap Press, Harvard University Press.

Rudnev, Vadim 2002. Characters and Personality Disturbances: Pathography and Metapsychology. Moscow: Klass (in Russian).

Sebeok, Thomas A 1979. The Sign and Its Masters. Texas: The University of Texas Press.

Sebeok, Thomas A.; Petrilli, Susan; Ponzio, Augusto 2001. Semiotica dall'io. Rome: Meltemi.

1 Acknowledgements. We are grateful to Prof. T. J. Lewis for his help in editing the paper. The research has been supported by Russian Foundation for Basic Research (Grant \# 03-06-80068). 
Seppänen, Jouko 2003. Autosemiosis: Self-reflection as a universal principle from semiotics of man, culture and nature to natural autosemiotics. In: Abstracts: International Summer Institute for Semiotic and Structural Studies. Imatra: ISISSS, 152-154.

Tarasti, Eero 2000. Existential Semiotics. Bloomington: Indiana University Press. Vijver, Gertrudis van de 1999. Psychic closure: A prerequisite for the recognition of the sign function? Semiotica 127(1/4): 613-630.

Uexküll, Jakob von 1928. Theoretische Biologie. Berlin: Springer.

Uexküll, Thure von 1986. Medicine and semiotics. Semiotica 61: 201-217.

- 1992. Varieties of semiosis. In: Sebeok, Thomas A.; Umiker-Sebeok, Jean (eds.), Biosemiotics: The Semiotic Web 1991. Berlin: Mouton de Gruyter, 455-470.

\section{Психиатрия в свободном падении: в поисках семиотической опоры}

Диагностика психического заболевания полностью опирается на оценку поведения больного, включая его речевое поведение. Поведение, в свою очередь, контролируется ситуацией, понимаемой как система знаков. Восприятие ситуации можно расценивать как функцию, зависимую от контекста, формируемого предшествующими ситуациями, структурирующими индивидуальный мир субъекта. Таким образом, мир не задан - он формируется в процессе активности человека. Мы полагаем, что различия в поведении, включая его аномальные формы, может быть объяснено не в терминах, описывающих характеры или болезни, а в рамках ситуаций, разыгрывающихся в индивидуальных мирах. Ситуация, в которой субъект воспринимает себя, является не просто местом в трехмерном пространстве в определенный момент времени, но частью его мира и эпизодом его жизни. Подобно тексту, состоящему из слов, индивидуальный мир составлен из ситуаций, каждая из которых требует определенного контекста для преодоления ее неоднозначности. Этот контекст порождается миром как целым по отношению к каждой входящей в него ситуации, выступающей как часть целого. В случае, если контекст не способен прояснить ситуацию, её неопределенность преодолевается путем активности, направленной на прогнозируемое изменение ситуации. Поэтому главными механизмами, определяющими адекватность представлений о мире субъекта, являются его целенаправленная активность, умение прогнозировать результаты своих действий и вносить в них необходимые коррекции. Слабость каждого из них неотвратимо ведет к формированию искаженной картины мира, ошибочной интерпретации ситуаций и, 
как следствие, - к неадекватным действиям, в конечном итоге приводящим к редуцированию активности как неэффективной. Дефицит активности, таким образом, становится ключевым фактором, ответственным за развитие болезни, являясь одновременно ее причиной и следствием. В периоды недостаточной активности субъекта возникают условия для патологического (и патогенного) функционирования знаков. Выделены следующие возможные варианты такого функционирования знаков: олигосемия (уменьшение количества воспринимаемых знаков); гипосемия (снижение значимости знака); гиперсемия (усиление значимости одних знаков в ущерб другим); амбисемия (неоднозначность знака, оставляющая ситуацию неясной); криптосемия (восприятие знаков, неочевидных для других наблюдателей) и парасемия (извращенное толкование знаков под влиянием ложного контекста).

\section{Psühhiaatria vabas langemises: semiootilise toe otsinguil}

Psüühikahäirete diagnostika tugineb täielikult haige käitumise hindamisele (kaasaarvatud tema kõneline käitumine). Käitumist omakorda kontrollib situatsioon, mida võib määratleda märgisüsteemina. Olukorra vastuvõttu võib hinnata kui kontekstist, mis on tingitud eelnevatest subjekti isiklikku maailma vormivatest situatsioonidest, sõltuvat funktsiooni. Seega maailm ei ole ette antud - see vormitakse inimtegevuse käigus. Me eeldame, et erinevusi käitumises, ka selle anomaalseid vorme, võib seletada mitte iseloomu või haigusi seletavate mõistete abil, vaid individuaalsetes maailmades lahtimängitavate situatsioonide raames. Situatsioon, milles subjekt ennast teadvustab, ei ole mitte lihtsalt koht kolmemõõtmelises ruumis kindlal ajahetkel, vaid tema maailma osa ja tema elu episood. Nagu tekst, mis koosneb sõnadest, nii koosneb individuaalne maailm situatsioonidest, milledest igaüks nõuab kindlat konteksti oma mitmetähenduslikkuse ületamiseks. See kontekst tekitatakse maailma kui terviku poolt iga selles sisalduva situatsiooni (mis on terviku osaks) suhtes. Juhul, kui kontekst ei ole võimeline situatsiooni selgitama, ületatakse selle määramatus situatsiooni muutusele (prognoositavale) suunatud aktiivsuse abil. Seetõttu on peamisteks mehhanismideks, mis määravad ära subjekti maailmanägemise adekvaatsuse, tema suunatud aktiivsus, oskus prognoosida oma tegevuse tulemusi ja viia neisse sisse vajalikke parandusi. Viga ühes neist mehhanismidest viib vältimatult moonutatud maailmapildi tekkimisele, olukordade eksliku tõlgendamise ja, kui taga- 
järg - mitteadekvaatsete tegevusteni, mis lõppkokkuvõttes toovad endaga kaasa aktiivsuse (kui mitteefektiivse) redutseerimise. Aktiivsuse defitsiit muutub seega võtmeteguriks, mis on vastutav haiguse arengu eest, olles ühtaegu nii selle põhjuseks kui ka tagajärjeks. Subjekti vähese aktiivsuse perioodidel tekivad tingimused märkide patoloogilise (ja patogeense) funktsioneerimise jaoks. Tuuakse välja järgmised võimalikud variandid: oligoseemia (vastuvõetavate märkide hulga kahanemine); hüposeemia (märgi olulisuse vähenemine); hüperseemia (ühtede märkide osatähtsuse suurenemine teiste arvelt); krüptoseemia (teiste vaatlejate jaoks arusaamatute märkide vastuvõtt) ja paraseemia (märkide väär tõlgendus vale konteksti mõjul). 